\title{
$H 4(D 10 S 170)$, a gene frequently rearranged in papillary thyroid carcinoma, is fused to the platelet-derived growth factor receptor $\beta$ gene in atypical chronic myeloid leukemia with $\mathrm{t}(5 ; 10)(\mathrm{q} 33 ; \mathrm{q} 22)$
}

Juerg Schwaller, Ema Anastasiadou, Danielle Cain, Jeff Kutok, Sarah Wojiski, Ifor R. Williams, Roberta LaStarza, Barbara Crescenzi, David W. Sternberg, Patrick Andreasson, Roberta Schiavo, Salvatore Siena, Cristina Mecucci, and D. Gary Gilliland

The molecular cloning of the $t(5 ; 10)(q 33$; q22) associated with atypical chronic myeloid leukemia (CML) is reported. Fluorescence in situ hybridization (FISH), Southern blot, and reverse transcriptasepolymerase chain reaction analysis demonstrated that the translocation resulted in an H4/platelet-derived growth factor receptor $\beta R$ (PDGF $\beta R$ ) fusion transcript that incorporated $5^{\prime}$ sequences from $\mathrm{H} 4$ fused in frame to $3^{\prime} P D G F \beta R$ sequences encoding the transmembrane, WW-like, and tyrosine kinase domains. FISH combined with immunophenotype analysis showed that $t(5 ; 10)(q 33 ; q 22)$ was present in $\mathrm{CD}^{+} 3^{+}$and $\mathrm{CD}_{14}{ }^{+}$cells but was not observed in $\mathrm{CD}^{+}$or $\mathrm{CD} 19^{+}$cells. $\mathrm{H} 4$ has previously been implicated in pathogenesis of papillary thyroid carcinoma as a fusion partner of RET. The H4/RET fusion incorporates 101 amino acids of $\mathrm{H} 4$, predicted to encode a leucine zipper dimerization domain, whereas the H4/PDGF $\beta R$ fusion incorporated an additional 267 amino acids of H4. Retroviral transduction of H4/PDGF $\beta R$, but not a kinaseinactive mutant, conferred factor-independent growth to $\mathrm{Ba} / \mathrm{F} 3$ cells and caused a T-cell lymphoblastic lymphoma in a murine bone marrow transplantation assay of transformation. Mutational analysis showed that the amino-terminal $\mathrm{H} 4$ leucine zipper domain (amino acids 5593), as well as $\mathrm{H} 4$ amino acids 101 to 386 , was required for efficient induction of factor-independent growth of $\mathrm{Ba} / \mathrm{F} 3$ cells. Tryptophan-to-alanine substitutions in the PDGF $\beta R$ WW-like domain at positions $566 / 593$, or tyrosine-to-phenylalanine substitutions at PDGF $\beta$ R positions 579/581 impaired factor-independent growth of $\mathrm{Ba} / \mathrm{F} 3$ cells. H4/PDGF $\beta R$ is an oncoprotein expressed in $t(5 ; 10)(q 33 ; q 22)$ atypical CML and requires dimerization motifs in the $\mathrm{H} 4$ moiety, as well as residues implicated in signal transduction by PDGF $\beta R$, for efficient induction of factorindependent growth of $\mathrm{Ba} / \mathrm{F} 3$ cells. (Blood. 2001;97:3910-3918)

๑) 2001 by The American Society of Hematology

\section{Introduction}

Constitutive activation of tyrosine kinases plays an important role in the pathogenesis of solid tumors and hematological malignancies. Chromosomal translocations and somatic mutations can cause deregulation of tyrosine kinase activity, and an emerging number of chromosomal translocations involving tyrosine kinases have been identified in leukemia. ${ }^{1}$ An important consequence of these translocations is the expression of fusion proteins with constitutive tyrosine kinase activity. The most studied example is the $\mathrm{t}(9 ; 22)(\mathrm{q} 34$; q22), resulting in expression of the BCR/ABL fusion, which is present in approximately $95 \%$ of patients with chronic myeloid leukemia (CML). ${ }^{2}$ Distinct genomic breakpoints within the $B C R$ gene result in different $B C R / A B L$ fusion variants (p230, p210, and p190). BCR causes oligomerization and activation of the ABL tyrosine kinase activity and a broad spectrum of downstream effectors, leading to transformation of hematopoietic cells. ${ }^{2}$ Other fusion genes involving tyrosine kinases associated with hematopoietic disorders include TEL/ABL, TEL/JAK2, and TEL/TRKC fusions involving the FGFR1 gene (ZNF198/FGFR1, CEP110/

From the Division of Hematology, Department of Medicine, and the Department of Pathology, Brigham and Women's Hospital, and the Howard Hughes Medical Institute, Harvard Medical School, Boston, MA; the Department of Pathology, Emory University, Atlanta, GA; Divisione di Oncologia-Ematologia, Ospedale Niguarda Ca' Granda, Milan, and Sezione di Ematologia, Università degli studi di Perugia, Italy.

Submitted June 6, 2000; accepted February 22, 2001.

Supported in part by a grant from the Swiss National Science Foundation (3100-056984.99) (J.S.); by the Associazione Italiana per la Richerca sul Cancro (C.M.); and by grants from the National Institutes of Health (P01CA66996-01 and P01OK50654) and the MarJo Foundation (D.G.G.).
$F G F R 1$, and $F O P / F G F R 1)$ and fusions involving the plateletderived growth factor receptor $\beta$ (PDGF $\beta R$ ) gene. ${ }^{3-6}$ PDGF $\beta R$, a member of the PDGF receptor family that includes the PDGF $\alpha$, colony-stimulating factor 1 receptor, steel-factor receptor (c-kit) and Flt3/FLK receptor, is characterized structurally by 5 immunoglobulinlike extracellular loops and a split intracellular tyrosine kinase domain. ${ }^{7}$ The first translocation involving the $P D G F \beta R$ gene was cloned from a chronic myelomonocytic leukemia (CMML) patient with $\mathrm{t}(5 ; 12)(\mathrm{q} 33 ; \mathrm{p} 13)$, resulting in fusion of the $5^{\prime}$ terminal region of the TEL(ETV6) gene (a member of the ets family of transcription factors) to the transmembrane and tyrosine kinase domains of the PDGFßR. ${ }^{8}$ Two other PDGF $\beta R$ fusion genes have subsequently been cloned. The $\mathrm{t}(5 ; 14)(\mathrm{q} 33 ; \mathrm{q} 32)$ and $\mathrm{t}(5 ; 7)(\mathrm{q} 33$; q11.2) rearrangements give rise to the $C E V 14 / P D G F \beta R$ and Huntingtin-interacting protein 1 (HIP1)/PDGF $\beta R$ fusion genes, respectively. ${ }^{9-10}$ The TEL/PDGF $\beta R$ and $H I P 1 / P D G F \beta R$ fusion genes have been associated with CMML, whereas the CEV14/ $P D G F \beta R$ fusion was cloned from a patient with acute monocytic

\section{J.S. and E.A. contributed equally to this work.}

Reprints: Juerg Schwaller, Institute de pathologie clinique, Hôpitaux univérsitaire de Genève, CMU, 1 Rue Michel Servet, Genéve, CH-1211, Switzerland; or Gary Gilliland, Division of Hematology/Oncology, Brigham and Women's Hospital, Harvard Medical School, 4 Blackfan Circle, Boston, MA, 02115 .

The publication costs of this article were defrayed in part by page charge payment. Therefore, and solely to indicate this fact, this article is hereby marked "advertisement" in accordance with 18 U.S.C. section 1734.

(C) 2001 by The American Society of Hematology 
leukemia in relapse. CMML is a subtype of myelodysplastic syndrome characterized by dysplastic monocytosis, variable bone marrow fibrosis, and progression of acute leukemia; its clinical phenotype is similar to CML, but is lacking the Philadelphia chromosome. ${ }^{11}$ TEL/PDGF $\beta R$ and HIP1/PDGF $\beta$ R transform hematopoietic cells in vitro and in vivo. ${ }^{12-15}$

Constitutive activation of tyrosine kinases due to chromosomal rearrangements or somatic mutations is also observed in solid tumors. ${ }^{16}$ Overexpression and somatic mutation of HER-2/p185neu and $c M E T$ are observed in breast carcinomas and renal or thyroid carcinoma. $^{17,18}$ Alterations of the RET proto-oncogene, which encodes for a receptor tyrosine kinase, are responsible for the development of multiple endocrine neoplasia types $2 \mathrm{~A}$ and $2 \mathrm{~B}$, Hirschsprung disease, and papillary thyroid cancer. ${ }^{19}$ Gene rearrangements leading to fusion of its tyrosine kinase domain to the $5^{\prime}$ terminal region of other genes generate the RET/PTC oncogenes, which are associated with human papillary carcinoma. ${ }^{20}$ Seven different types of RET rearrangement (PTC 1-7) have been molecularly characterized. ${ }^{21}$ RET/PTCl is the result of a paracentric inversion of the long arm of chromosome $10 \mathrm{inv}(10)(\mathrm{q} 11.2 \mathrm{q} 21)$, fusing the terminal amino acid 101 of the H4(D10S170) gene to the intracellular split tyrosine kinase domain of RET. This rearrangement is observed in approximately $20 \%$ of human papillary carcinomas. $^{22}$ The H4(D10S170) gene encodes for a 585-amino acid protein with no significant homology to known genes and has unknown function. ${ }^{23}$ In vitro studies showed that the leucine zipper region of $\mathrm{H} 4$ included in the fusion is responsible for the dimerization of the PTC1 oncoprotein and is essential for tyrosine hyperphosphorylation and transformation in vitro. ${ }^{24}$

Here we present the molecular characterization of a patient with atypical CML with $\mathrm{t}(5 ; 10)(\mathrm{q} 33 ; \mathrm{q} 22)$. Initial classical karyotypic analysis showed a reciprocal translocation $\mathrm{t}(5 ; 10)$ in myeloid progenitor cells of the patient. ${ }^{25}$ Using fluorescence in situ hybridization (FISH), Southern blot, and rapid amplification of complementary DNA (cDNA) ends (RACE)-polymerase chain reaction (PCR) techniques, we show that the translocation is present only in the patient's myeloid cells and results in fusion of the H4(D10S170) gene to the transmembrane and tyrosine kinase domains of the PDGF $\beta R$. In vitro experiments show that expression of the $H 4 / P D G F \beta R$ fusion gene transforms interleukin-3 (IL-3)-dependent $\mathrm{Ba} / \mathrm{F} 3$ cells to factor independence. Moreover, in vivo transforming activity of the H4/PDGF $\beta$ R fusion is demonstrated in a murine bone marrow reconstitution assay. These data show that rearrangements of the $H 4(D 10 S 170)$ gene can not only contribute to carcinogenesis by activating RET in papillary carcinomas but also lead to hematopoietic transformation in an $H 4 / P D G F \beta R$ fusion gene associated with atypical CML.

\section{Materials and methods}

\section{FISH and "fiction" analysis}

FISH was performed as previously described. ${ }^{26}$ The breakpoint on chromosome 5 was investigated by means of the $\operatorname{cosmid}$ probe $\operatorname{cosmid} B(\cos B)$ (kindly provided by Dr W. M. Roberts, M. D. Anderson Cancer Center, Houston, TX), ${ }^{8}$ assigned to the $P D G F \beta R$ gene at band $5 \mathrm{q} 33$. The breakpoint on chromosome 10 was narrowed by applying 2 yeast artificial chromosomes (YACs), $781 F 5$ and $876 H 2$, for bands $10 \mathrm{q} 21.3$ and 10q22.1, respectively. In each experiment, the centromeric chromosome 10 probe D10Z1 was added. Dual-color FISH was performed with $\cos B$ labeled with digoxigenin, and PAC29F6 for the H4/D10S170 gene, ${ }^{27}$ labeled with biotin. The "fiction" method was adapted from Weber-Matthiesen et al. ${ }^{28}$
Cytospins were prepared from mononuclear cells that were obtained from the patient's peripheral blood and stored at $-20^{\circ} \mathrm{C}$ without fixation. After thawing, the slides were fixed in acetone at room temperature for 10 minutes and air-dried. They were then incubated with a monoclonal antibody for 30 minutes at room temperature, and staining was performed in a 3-step technique with the following antibodies: Cy3-conjugated polyclonal goat antimouse, rabbit antigoat, and donkey antirabbit (Jackson Laboratory, Bar Harbor, ME; Dianova, Hamburg, Germany); and the following monoclonal antibodies: anti-CD3, anti-CD13, anti-CD14, antiCD20, and anti-CD19 (all from Dako, Glostrup, Denmark). After immunostaining, the slides were fixed in Carnoy fixative (methanol-to-acetic acid, 3:1) for 10 minutes, followed by $1 \%$ paraformaldehyde for 10 minutes, washed in distilled water; dehydrated in an ethanol series; and hybridized with $\cos \mathrm{B}$ for the $P D G F \beta R$. The biotinylated DNA was detected by incubation with fluorescein isothiocyanate (FITC)-conjugated avidin, followed by biotinylated goat antiavidin antibody, followed by a second incubation with FITC-conjugated avidin. The immunophenotype and hybridization signals were evaluated simultaneously on an Olympus microscope with filter sets for Cy-3 and FITC (Olympus Optical, Japan).

\section{DNA isolation and Southern blot analysis}

DNA was isolated from buffy-coat preparations of peripheral blood from the patient and a normal individual after informed consent had been obtained. The patient's clinical history has been described previously. ${ }^{25}$ DNA was prepared by means of a Purgene DNA isolation kit (Gentra Systems, Minneapolis, MN) according to the manufacturer's protocol. After enzymatic digestion with restriction endonucleases and electrophoretic separation, the genomic DNA was blotted to Hybond $-\mathrm{N}^{+}$nylon membranes (Amersham, Arlington Heights, IL) by alkaline transfer. The $P D G F \beta R$ genomic probe was a 1.1-kilobase $(\mathrm{kb})$ HindIII-XhoI fragment prepared from PDGF $\beta R \operatorname{cosB} .{ }^{8}$ Probes were labeled with ${ }^{32} \mathrm{P}$ by random priming, and Southern hybridizations were performed as described. ${ }^{29}$

\section{Breakpoint cloning}

We isolated $1.6 \mu \mathrm{g}$ poly(adenylic acid), or poly(A), RNA from $60 \times 10^{6}$ cells from the patient's buffy-coat cells using the Quickprep Micro messenger RNA purification kit (Pharmacia Biotech, Uppsala, Sweden). Anchored PCR was performed to clone the chromosome 10 partner gene by means of a 5'-3 RACE kit (Boehringer Mannheim, Mannheim, Germany). In brief, $500 \mathrm{ng}$ poly(A) RNA was reverse-transcribed by means of avian myeloblastosis virus (AMV) reverse transcriptase and $P D G F \beta R$ oligonucleotide primer $1873 \mathrm{R}$ at $55^{\circ} \mathrm{C}$. $P D G F \beta R$ primers have been previously described in detail..$^{8,10} \mathrm{~A}$ poly-A tail was appended to the purified cDNA by means of terminal transferase and deoxyadenosine triphosphate. The tailed cDNA was amplified $\left(94^{\circ} \mathrm{C}\right.$ for 2 minutes, $94^{\circ} \mathrm{C}$ for 15 seconds, annealing at $58^{\circ} \mathrm{C}$ for 30 seconds, elongation for 40 seconds, and cycle elongation of 20 seconds after 10 cycles of a total of 35 cycles) by means of oligo deoxythymidine anchor primer (5'-GAC CAC GCG TAT GCA TGT CGA CTT TTT TTT TTT TTT TT- $3^{\prime}$ ) and an internal $P D G F \beta R$ primer $1848 \mathrm{R}$. We re-amplified $1 \mu \mathrm{L}$ of the diluted first-round PCR product (1:20) in a nested PCR reaction using the same conditions as the first round with a PCR anchor primer (5'-GAC CAC GCG TAT CGA TGT CGA C-3') and the $P D G F \beta R$ internal primer $1829 \mathrm{R}$. Specific bands were detected after 2 rounds of PCR by direct visualization on an agarose gel. Two fragments, 250 base pairs (bp) and $400 \mathrm{bp}$, appeared in 2 separate experiments and were subcloned into pCR2.1-TOPO (Invitrogen, Carlsbad, CA) and sequenced. The DNA sequence was then compared with sequences in the GenBank by means of the advanced BlastN screening.

\section{Reconstruction of a full-length fusion cDNA for expression experiments}

A full-length cDNA clone of the fusion was generated as follows. The H4/PDGF $\beta R$ breakpoint was amplified by means of a forward $P D G F \beta R$ primer with H4-specific anchor that incorporates a unique $S t u$ I site $5^{\prime}$ of the breakpoint, together with a PDGF $\beta$ R reverse primer covering a unique 
SacII site 250 bp $3^{\prime}$ of the breakpoint by means of Pfu-polymerase (Stratagene, San Diego, CA) according to the manufacturer's recommendations. The product was subcloned into pcDNA3 (Invitrogen) containing an $H 4(D 10 S 170)$ full-length cDNA clone in reverse orientation, cloned from $p G E M 3 Z-H 4$ cDNA, ${ }^{23}$ and sequenced to confirm that no mutations had been introduced in the PCR step. The $3^{\prime}$ end of the $P D G F \beta R$ cDNA was added by isolating the fragment from pBluescript.TEL/PDGF $\beta R C D N A^{8}$ and cloning it into the unique SacII site. This full-length reverse H4/ PDGF $\beta R$ clone was then subloned in pBluescript, pMSCVneo, and pMSCV-GFP (the pMSCV retroviral expression vectors were kind gifts from R. Hawley, University of Toronto, ON, Canada, and W. Pear, University of Pennsylvania, Philadelphia). Expression of the H4/PDGF $\beta R$ fusion protein from the full-length $H 4 / P D G F \beta R$ cDNA clone was confirmed by means of an in vitro transcription-translation reaction kit (Promega, Madison, WI) (not shown).

\section{Expression of H4/PDGF $\beta R$ in primary patient cells}

Expression of the H4/PDGF $\beta$ R fusion was studied in peripheral blood cells (buffy-coat preparation) from the patient and in cells of a normal healthy donor. Total RNA was isolated by means of an RNA isolation kit (RNA-STAT-60) (Tel-Test, Friendswood, TX) followed by reverse transcription of $1 \mu \mathrm{g}$ total RNA by means of AMV-RT (1st Strand cDNA Synthesis Kit) (Boehringer Mannheim) following the manufacturer's instructions. A nested-PCR approach was used as follows: H4.300F (5'CAA GCC AGG GCT GAG CAG GAA GAA TTC $3^{\prime}$ ) and H4.720F (5'GCT CCA CCA TCG CCT AGA GAT ATC TCC ATG 3'), each with $P D G F \beta R$ (1848R) for the first cycle; $1 \mu \mathrm{L}$ of a 1:10 dilution of the first round was used for the second round with the same $\mathrm{H} 4$ primers in combination with the PDGF $\beta R$ $(1829 \mathrm{R})$ primer. The PCR cycle parameters were 10 cycles at $94^{\circ} \mathrm{C}$ for 30 seconds, $65^{\circ} \mathrm{C}$ (decreasing $1^{\circ} \mathrm{C}$ per cycle) for 30 seconds, and $72^{\circ} \mathrm{C}$ for 30 seconds, followed by 30 cycles of $94^{\circ} \mathrm{C}, 55^{\circ} \mathrm{C}$, and $72^{\circ} \mathrm{C}$ for 30 seconds each and a final extension of 7 minutes at $72^{\circ} \mathrm{C}$. To detect the reverse PDGFßR/H4 product, the PDGFßR.F1 (5'GGA GAC TAA CGT GAC GTA CTG $3^{\prime}$ ) primer was used for the first round in combination with H4.R1 (5'CAG GAC TGT TGC TTC TCC GTG 3') and H4.R2 (5'GCT CCA TTG GAT GAG TCC CAA C $3^{\prime}$ ) primers; for the second round, the PDGFßR.F2 (5'GAG TTT GAG GTG GTG AGC AC 3') primer was used with the same $\mathrm{H} 4$ primers. For amplification of the $\mathrm{H} 4$ gene, primers H4.300F and H4.720F with H4.R2 were used for the first round, followed by a second round with the H4.R1 reverse primer. To assess the quality of the transcribed cDNA, primers for $\beta$-actin were used: $\beta$-actin. $2282 \mathrm{~F}$ (5'GGG AAA TCG TGC GTG ACA TT $3^{\prime}$ ) and $\beta$-actin.2583R (5'GGA GTT GAA GGT AGT TTC GTG 3').

\section{Generation of H4/PDGF $\beta$ R mutants and transformation studies}

Mutants were generated by PCR by means of Pfu-polymerase (Stratagene) according to the manufacturer's recommendations and subcloned into the retroviral expression vector $M S C V-P G K$-neo and $M S C V$-IRES-GFP. As shown in Figure 5A, mutations that were generated included $M S C V-H 4 /$ $P D G F \beta R-W W(\mathrm{~W} \rightarrow \mathrm{A}$ [single-letter amino acid codes] substitutions at positions 566/593 of the PDGF $\beta$ R moiety); an H4/PDGF $\beta R-F 2$ mutant analogous to the TEL/PDGF $\beta R-F 2$ previously described ${ }^{15}$; a kinaseinactive $M S C V-H 4 / P D G F \beta R-634 R$ mutant, ${ }^{12} M S C V-H 4 / P D G F \beta R \Delta L Z$ lacking the H4(D10S170) leucine zipper domain ( $H 4$ amino acids 55-93); and $M S C V-H 4 / P D G F \beta R-\triangle E X$ lacking amino acids 101-368 of $H 4$ (D10S170) between the $H 4 / R E T$ and $H 4 / P D G F \beta R$ breakpoints. All PCR-generated fragments were sequenced after subcloning to confirm the correct sequence, and the cDNA clones were translated in vitro to confirm expression of a protein of the expected molecular weight. To test for transforming ability, $H 4 / P D G F \beta R$ clones were expressed in the IL-3-dependent hematopoietic cell line $\mathrm{Ba} / \mathrm{F} 3$, by retroviral transduction with the use of retroviral supernatants generated by transient double transfection of pMSCV and pIk6 into 293 T cells as described previously. ${ }^{29}$ At 48 hours after infection, cells were washed and screened for survival in medium lacking IL-3. The same experiment was also performed by means of stably transfected cells with
MSCV-H4/PDGFRR-PGK-neo and the mutants, preselected in G418 (1 $\mathrm{mg} / \mathrm{mL}$ ), for 7 to 10 days. $^{29}$

To characterize the in vivo transforming activity of the H4/PDGF $\beta R$ fusion, a murine bone marrow transplantation (BMT) assay was performed as described previously. ${ }^{15,29}$ Briefly, donor mice were treated with 5-FU $(150 \mathrm{mg} / \mathrm{kg}) 5$ days prior to harvest of bone marrow. Bone marrow cells were incubated for 48 hours ex vivo in media that included IL-3, IL-6, and stem cell factor as described ${ }^{15,29}$ and transduced by spinfection with viral supernatants of the murine ecotropic retrovirus MSCV containing the constructs noted in the text. One million transduced whole bone marrow cells were then injected by tail vein into lethally irradiated syngeneic recipeint mice $(\mathrm{Balb} / \mathrm{C}, 450 \mathrm{cGY} \times 2)$ as previously described. ${ }^{15,29} \mathrm{~A}$ total of 16 recipient mice were transplanted with bone marrow transduced with MSCV retrovirus containing the full-length $H 4 / P D G F \beta R$ fusion gene. Preparation of tissues for histologic examination and flow cytometric analysis was performed as described previously. ${ }^{29}$

\section{Results}

\section{The PDGF $\beta R$ gene is rearranged in myeloid lineage cells harboring the $t(5 ; 10)(q 33 ; q 22)$}

To localize the breakpoint, FISH of metaphase chromosome preparations of bone marrow cells from the patient with atypical CML and $\mathrm{t}(5 ; 10)$ as a single karyotypic abnormality was performed. As described previously, the abnormal karyotype, as assessed by conventional cytogenetics, was present in myeloid precursor cells. ${ }^{25}$

FISH analysis with a chromsome $5 \mathrm{q} 33$-specific probe, $\cos B$, which includes a portion of the genomic sequence of the $P D G F \beta R$ gene, gave a hybridization signal on the normal 5 , and a split hybridization signal on the $\operatorname{der}(5)$ and the $\operatorname{der}(10)$ generated by the $\mathrm{t}(5 ; 10)$ (Figure 1A). YACs $781 \mathrm{~F} 5$ and $876 \mathrm{H} 2$, which are specific for $10 \mathrm{q} 21.3$ to $\mathrm{q} 22.1$, hybridized with the normal chromosome 10 and with der(5). No signals were present on $\operatorname{der}(10)$ (Figure 1B). To assess whether $t(5 ; 10)$ was present only in the patient's myeloid cells, a combination of immunostaining and FISH was performed. As shown in Figure 2A-B, hybridization with $\cos B$ resulted in 3 hybridization signals in myeloid progenitor cells $\left(\mathrm{CD} 13^{+}, \mathrm{CD} 14^{+}\right)$, whereas only 2 signals were observed in $\mathrm{T}\left(\mathrm{CD}^{+}\right)$or $\mathrm{B}$ lineage $\left(\mathrm{CD} 19^{+}, \mathrm{CD} 20^{+}\right)$cells (Figure 2C-D). Within the sensitivity of this assay, these data indicate the presence of the $\mathrm{t}(5 ; 10)$ balanced reciprocal in myeloid lineage cells, but not in lymphoid cells of this patient with atypical CML.

The clinical, cytogenetic, and FISH data from this patient were similar to those observed in previously reported cases of CMML with the $\mathrm{t}(5 ; 12)(\mathrm{q} 33 ; \mathrm{p} 12) T E L / P D G F \beta R$ and the $\mathrm{t}(5 ; 7)(\mathrm{q} 33 ; \mathrm{q} 11.2)$ $H I P 1 / P D G F \beta R$ fusion genes, respectively. ${ }^{8,10}$ In those previous examples, the PDGF $\beta R$ cases, the chromosomal breakpoint was identified by means of a 1.1-kb XhoI/HindIII genomic PDGF $\beta R$ probe derived from $\cos B{ }^{8,10}$ Southern blot analysis using this genomic $P D G F \beta R$ fragment as a probe demonstrated rearrangement of the $P D G F \beta R$ gene in 3 out of 5 restriction-enzyme digests of the patient's DNA, but not in the normal cDNA (Figure 3). These data demonstrated that the chromosome 5 breakpoint was at or near the same intron of the $P D G F \beta R$ gene as in the $\mathrm{t}(5 ; 12)(\mathrm{q} 33 ; \mathrm{p} 13)$ and $\mathrm{t}(5 ; 7)(\mathrm{q} 33 ; \mathrm{q} 11.2)$ translocations..$^{8,10}$

\section{Identification of the $H 4(D 10 S 170)$ gene as fusion partner to the} $P D G F \beta R$ gene in $\mathrm{t}(5 ; 10)(\mathrm{q} 33 ; \mathrm{q} 22)$

The chromosome 10 partner was identified by means of anchored PCR with $P D G F \beta R$ primers to amplify the fusion transcript from 
the patient's peripheral blood cell cDNA. Analysis of the amplified cDNA clones showed 2 clones of 250 and 400 bp of non-PDGF $\beta R$ sequence encoding an open reading frame fused to the transmembrane and tyrosine kinase-encoding regions of the $P D G F \beta R$ gene (Figure 4A). A database search demonstrated that this sequence was identical to the coding sequence of the H4(D10S170) gene located on chromosome 10q21.23

The H4(D10S170) cDNA is ubiquitously expressed and encodes a protein of unknown function and no significant homology to any mammalian gene. The protein has a predicted alpha helical conformation similar to the myosin heavy-chain tail, 2 putative leucine zipper domains, and a putative SH3 domain at the
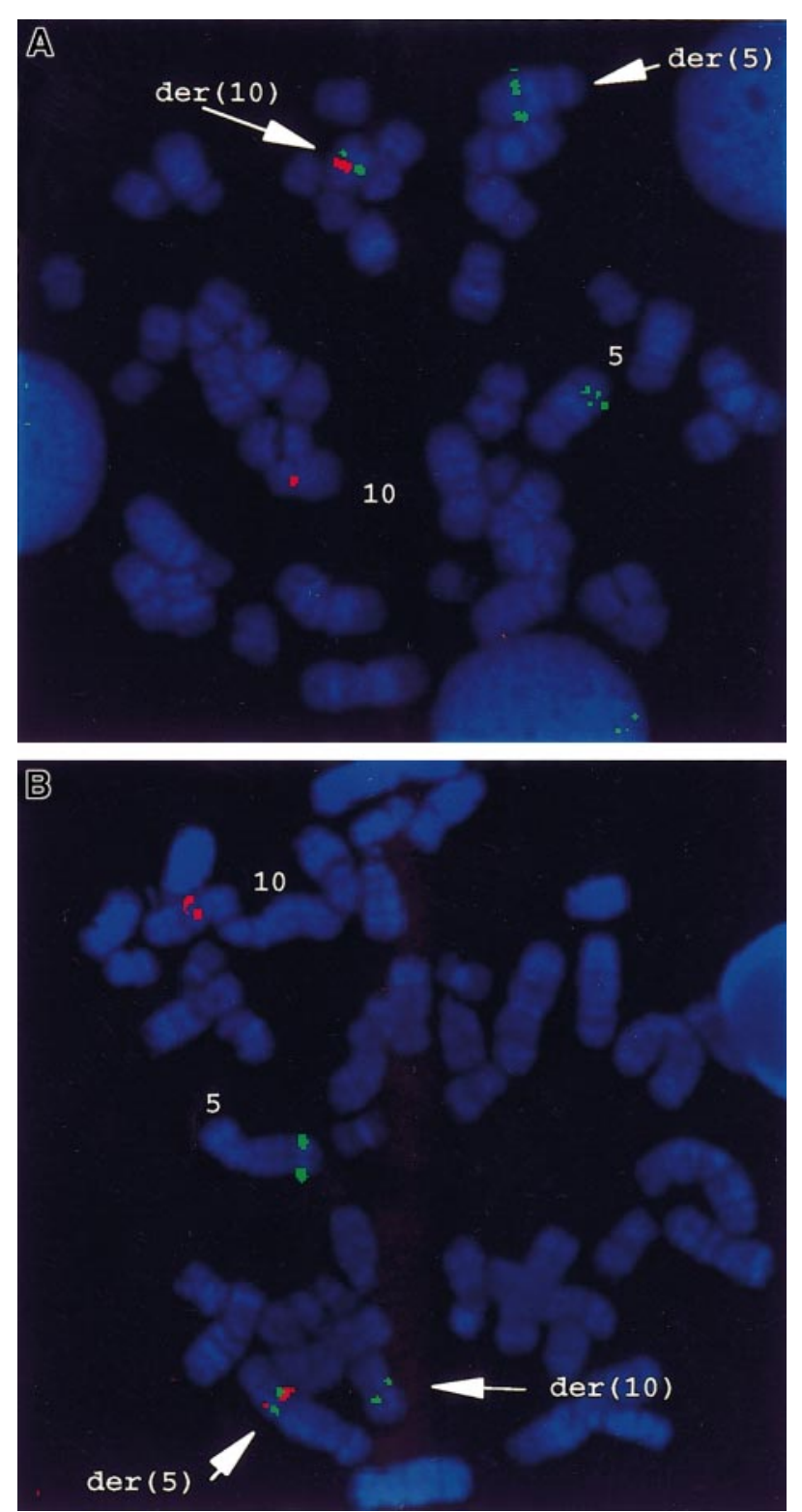

Figure 1. FISH analysis of the $t(5 ; 10)(q 33 ; q 22)$ in primary patient cells. (A) FISH analysis using PDGF $\beta R$ - and H4-locus-specific probes. CosB, a PDGF $\beta$ R-specific genomic probe, gave 3 hybridization signals on normal 5 and on $\operatorname{der}(5)$ and $\operatorname{der}(10)$ originating from $\mathrm{t}(5 ; 10)$, respectively. Both YACs $781 \mathrm{~F} 5$ and $876 \mathrm{H} 2$, for $10 \mathrm{q} 21.3$ to q22.1, hybridized with the normal chromosome 10 and with the der(5). No signals were present on $\operatorname{der}(10)$. (B) Dual-color FISH with CosB (red) and PAC29F6 (green) showed the presence of a fusion signal on der(5), whereas a green signal (PAC29F6) was present on the normal 10 , and a red signal was seen (CosB) on the normal 5 and the $\operatorname{der}(10)$.
C-terminus, and it has been suggested to be a cytoskeletal protein. ${ }^{23}$ $H 4(D 10 S 170)$ is involved in RET rearrangements as a result of a paracentric inversion of chromosome 10q inv(10)(q11.2q21) associated with about $25 \%$ of human papillary thyroid carcinomas. ${ }^{20,23,30}$ In these carcinomas, the genomic breakpoint in $H 4(D 10 S 170)$ occurs in intron $1 .^{31,32}$ The resulting oncogene RET/PTC1 (papillary thyroid carcinoma gene 1) is formed by in-frame fusion of $5^{\prime}$ sequences from the H4(D10S170) gene (amino acids 1-101) to the RET gene, $39 \mathrm{bp} \mathrm{3'}$ of RET tyrosine kinase-coding sequences. ${ }^{20}$ In contrast to RET/PTC1 (Figure 4A), the breakpoint within the $H 4$ gene in $\mathrm{t}(5 ; 10)(\mathrm{q} 33 ; \mathrm{q} 21)$ lies $3^{\prime}$ of the breakpoint in the H4/RET fusion and fuses the first 368 amino acids of H4(D10S170) to the transmembrane and tyrosine kinase domains of the $P D G F \beta R$. To confirm expression of the $H 4 / P D G F \beta R$ fusion transcript in primary leukemic cells from the patient, reverse transcriptase (RT) PCR analysis was performed with 2 different pairs of $H 4 / P D G F \beta R$ primers. H4/PDGF $\beta R$ fusion transcripts were detected in the patient's peripheral blood cells but not in the normal control (Figure 4B). Expression of the reciprocal $P D G F \beta R / H 4$ fusion was not detected (data not shown), which is similar to results obtained in patient samples harboring the TEL/PDGF $\beta R$ and HIP1/PDGF $\beta R$ gene rearrangements. ${ }^{8,10}$ The normal $H 4(D 10 S 170)$ allele is deleted in a papillary thyroid cancer cell line (TPC-1) carrying a RET/PTC1 fusion gene. ${ }^{27}$ However, FISH analysis of $\mathrm{t}(5 ; 10)(\mathrm{q} 33 ; \mathrm{q} 21)$ cells showed no evidence of loss of the residual allele, and the $H 4(D 10 S 170)$ transcript was detectable in leukemic cells containing the translocation, indicating the presence of a functional residual $H 4$ (D10S170) allele (Figure 4C). Collectively, these data demonstrate that $\mathrm{t}(5 ; 10)(\mathrm{q} 33 ; \mathrm{q} 21)$ results in fusion of $H 4(D 10 S 170)$ to the $P D G F \beta R$ and that the $H 4 / P D G F \beta R$ fusion transcript, but not the reciprocal, is expressed in the patient's myeloid lineage cells.

\section{The H4/PDGF $\beta$ R fusion gene has transforming activity in vitro and in vivo}

To characterize the biological properties of the H4/PDGF $\beta R$ fusion, a full-length cDNA clone was constructed and subcloned into MSCV-PGK-neo and MSCV-IRES-GFP retroviral expression vectors (Figure 5A). Murine IL-3-dependent hematopoietic Ba/F3 cells were retrovirally transduced with $M S C V-H 4 / P D G F \beta R$ and assayed for growth-factor independence. $\mathrm{Ba} / \mathrm{F} 3$ cells expressing H4/PDGF $\beta R$ were generated either by retroviral transduction with $M S C V-H 4 / P D G F \beta R$-neo and selection with $\mathrm{G} 418$ or by transduction with $M S C V-H 4 / P D G F \beta R-G F P$ without selection (data not shown). These cells were able to sustain log-phase growth in the absence of IL-3, whereas Ba/F3 cells transduced with empty vector died rapidly after IL-3 depletion (Figure 5B). In vitro transforming activity of the H4/RET and the TEL/PDGFßR is dependent on the presence of the leucine zipper and pointed dimerization domains in H4 and TEL, respectively. ${ }^{12,24}$ To determine which structural components of the H4/PDGF $\beta$ R fusion were required for transformation of $\mathrm{Ba} / \mathrm{F} 3$ cells to factor-independent growth, several mutants were constructed (Figure 5A). MSCV-H4/PDGF $\beta R \Delta L Z$ lacks the 5'-leucine zipper domain (amino acids 55-93) and $M S C V-H 4 / P D G F \beta R-\triangle E X$ lacks the portion of $H 4(D 10 S 170)$ gene that is present in the $H 4 / P D G F \beta R$ fusion but absent in the corresponding H4/RET fusion (H4 amino acids 101-368). Thus, transformation of $\mathrm{Ba} / \mathrm{F} 3$ cells to factor-independent growth by H4/PDGFßR, in a 4-day assay after IL-3 deprivation, required the presence of the amino-terminal leucine zipper domain. In addition, 

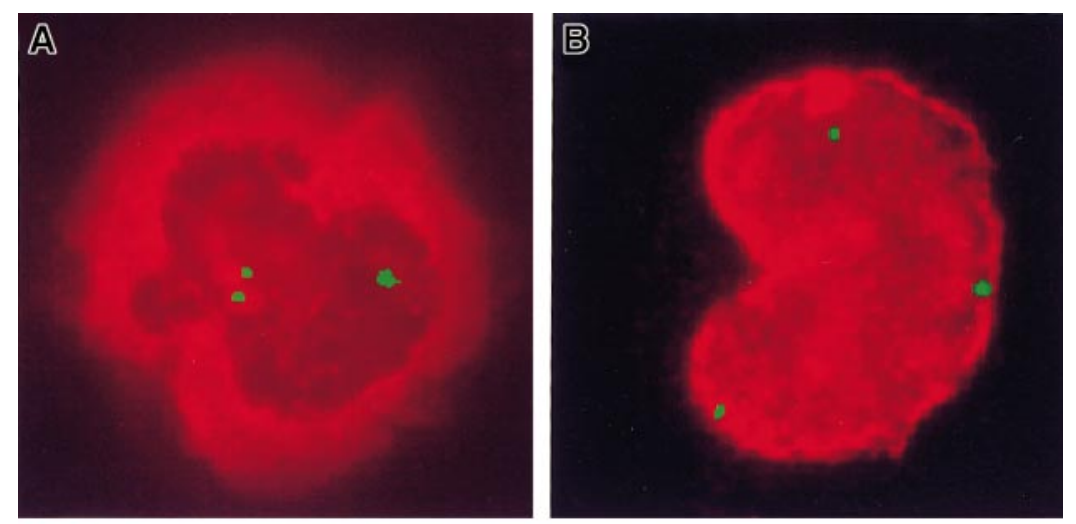

Figure 2. Simultaneous phenotypic and genotypic analysis on a cytospin prepared from peripheral blood cells. Monoclonal antibody (red), $P D G F \beta R$ probe (green). (A, B) CosB gave 3 hybridization signals on $\mathrm{CD}_{13}{ }^{+}$or $\mathrm{CD} 14^{+}$cells, respectively, indicating the presence of the $t(5 ; 10)(q 33 ; q 22)$ with a split PDGF $\beta R$ signal in these myeloid lineage cells. (C, D) Only 2 signals were present in the $\mathrm{CD}^{+}$or $\mathrm{CD}_{1} 9^{+}$cells, respectively, indicating that these lymphoid cells lack the translocation.
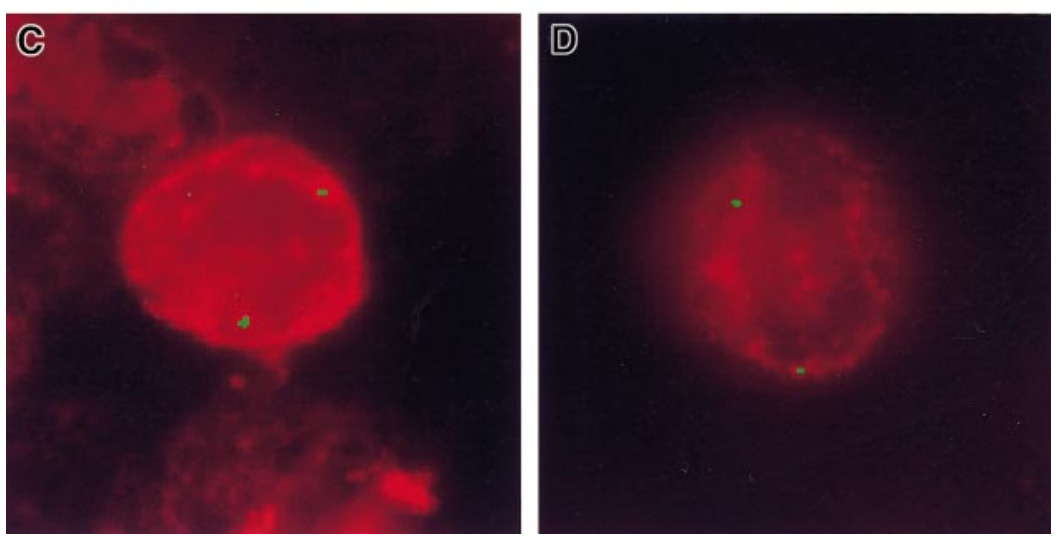

$H 4$ coding sequences that are present in $H 4 / P D G F \beta R$ but absent in $H 4 / R E T$ were required for full transforming activity (Figure $5 \mathrm{~B}$ ).

A recent report has proposed an important role for the WW-like domain (amino acids 566/593), which is C-terminal to the PDGF $\beta R$ transmembrane region, for normal signal transduction mediated by the native PDGF $\beta R .{ }^{33}$ We found that a WW mutation (Figure 5A) also impaired the ability of the H4/PDGF $\beta R$ fusion to confer factor-independent growth to $\mathrm{Ba} / \mathrm{F} 3$ cells (Figure $5 \mathrm{~B}$ ). In addition, an $H 4 / P D G F \beta R$ F2 mutant ( $\mathrm{Y} \rightarrow \mathrm{F}$ mutants of the tyrosines 579 and 581, near the PDGF $\beta R$ transmembrane domain) was generated $^{34}$ (Figure 5A). These tyrosines are important for PDGF $\beta R$ signal transduction mediated by interaction with the $\mathrm{SH} 2$ containing SRC protein and STAT5 family members, ${ }^{35}$ and an analogous $T E L / P D G F \beta R-F 2$ mutant cannot induce myeloproliferative disease in murine BMT models. ${ }^{15}$ The H4/PDGF $\beta R$-F2 mutant also had impaired ability to induce factor-independent growth in Ba/F3 cells (Figure $5 \mathrm{~B}$ ). Western blot analysis of whole cell lysates using an anti-PDGF $\beta$ R antibody demonstrated expression of H4/PDGF $\beta R$ and related mutants at the expected molecular weights. (Figure 5C). No differences in tyrosine kinase activity could be detected as a consequence of these mutations as assessed by phosphotyrosine blots to detect autophosphorylation.

We tested the transforming activity of the H4/PDGF $\beta$ R fusion in vivo using a murine BMT assay. In previous studies, we demonstrated that transplantation of primary bone marrow cells that have been transduced with a retrovirus encoding a tyrosinekinase fusion gene results in induction of a lethal hematological disease in syngeneic recipient animals. ${ }^{15,29,36,37}$ Murine bone marrow was transduced with retroviral supernatants containing $M S C V$ H4/PDGF $\beta R$-GFP (16 animals), MSCV-H4/PDGF $\beta R$-634R-GFP (8 animals), and MSCV-TEL/PDGF $\beta R$-GFP (8 animals), and one million cells were transplanted by tail-vein injection into lethally irradiated syngeneic hosts. Control animals that received bone marrow transduced with the TEL/PDGF $\beta R$ retrovirus developed a rapidly lethal myeloproliferative disease with a latency of 25 to 30 days, as previously reported, ${ }^{15}$ whereas the kinase-inactive $M S C V$ H4/PDGF $\beta R$-634R-GFP caused no disease with 8 months of follow-up. In contrast, H4/PDGF $\beta R$ induced an aggressive T-cell lymphoblastic lymphoma/leukemia with prolonged latency (median, 150 days post-transplant), as assessed by morphologic (Figure 6A-C) and flow-cytometric analysis (Figure 6D). Retroviral integration was confirmed by Southern blot analysis (Figure

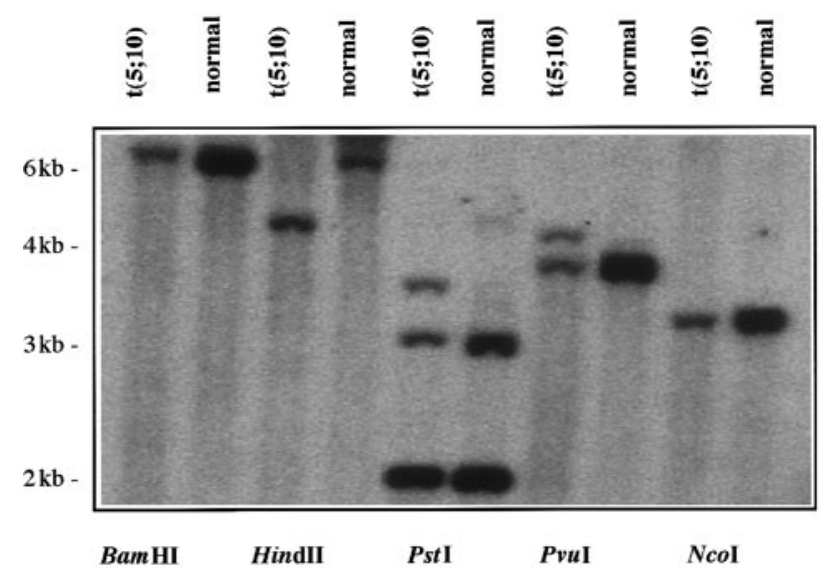

Figure 3. Southern blot analysis of DNA from leukemia cells with $t(5 ; 10)(q 33$ q22). Genomic DNA was isolated mononuclear cells from Ficoll-Hypaque density gradient sedimentation of peripheral blood from the patient and a normal donor and was digested $(10 \mu \mathrm{g})$ with 5 different restriction endonucleases. The Southern blot was probed with a 1.1-kb (Xhol/HindllI) genomic PDGF $\beta$ R probe. Rearrangements were evident in patient DNA when the restriction endonucleases HindIII, Pstl, or Pvul were used (lanes 3-8). 
From www.bloodjournal.org at UNIV STUDI MILANO Biblioteca Polo San Paolo on September 17, 2019. For personal use only.

Figure 4. Structure and RT-PCR of H4/PDGFBR fusion. (A) Structure of the H4/PDGF $\beta R$ fusion. $\mathrm{H} 4$ is fused at amino acid 381 in frame to the $P D G F \beta R$ gene beginning at amino acid 528. The breakpoint within $P D G F \beta R$ is identical to that in the TEL/PDGF $\beta R$ and HIP1/PDGF $\beta R$ fusions. (B) RT-PCR of the H4/PDGFBR fusion. RNA was extracted from leukemic cells containing the $\mathrm{t}(5 ; 10)(\mathrm{q} 33 ; \mathrm{q} 22)$ and from a normal donor and was used as a template for RT-PCR as described in "Materials and methods." Two sets of $H 4 / P D G F \beta R$ primers, denoted $300 \mathrm{~F}$ and $720 \mathrm{~F}$, were used. $H 4 / P D G F \beta R$-specific transcripts were detected in the leukemic sample but not in the normal control. (C) RT-PCR of $H 4(D 10 S 170)$ was also performed to demonstrate H4(D10S170) expression in both normal and patient samples. As expected, signal was seen in patient, donor, and $\mathrm{H} 4$ containing plasmid with the use of the $720 \mathrm{~F}$ primer set, but not in the H4/PDGF $\beta R$ plasmid.

A

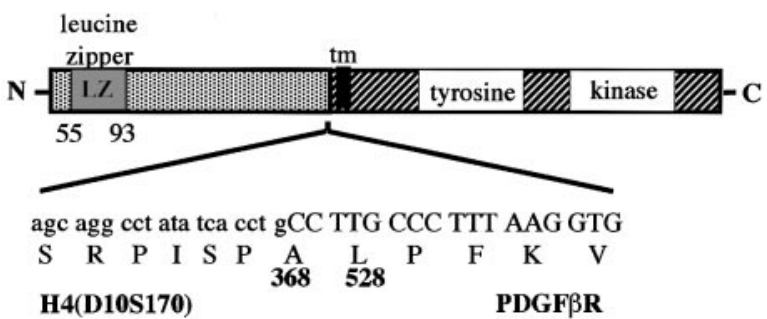

B

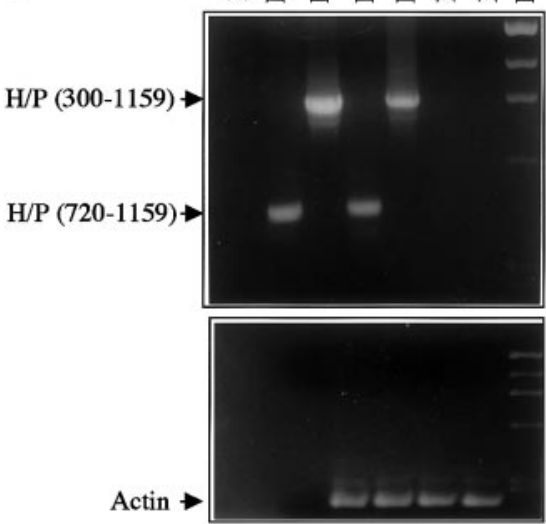

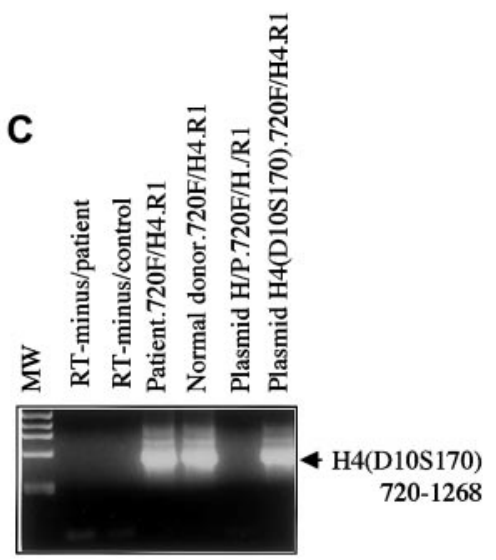

B

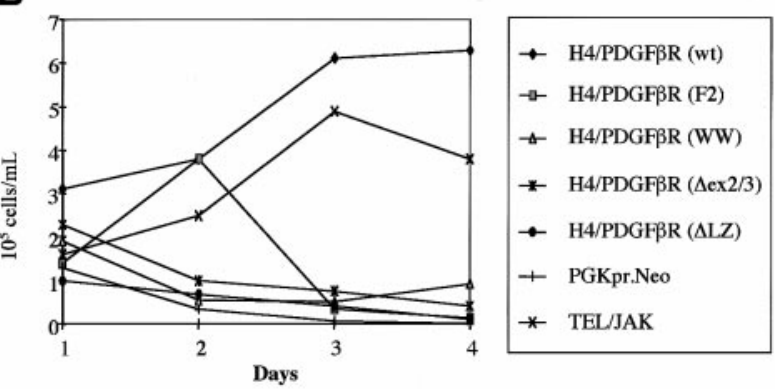

C
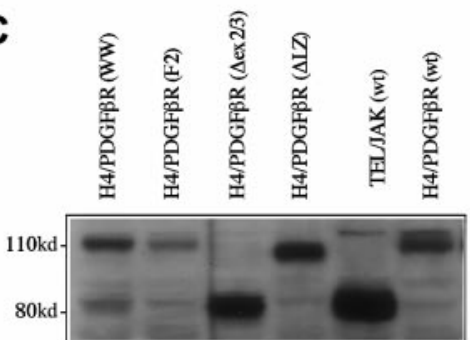

Figure 5. Structure and transforming properties of $H 4 / P D G F \beta R$ and related mutants. (A) Schematic diagram of $H 4 / P D G F \beta R$ fusion and related mutants. $H 4 / P D G F \beta R$ $(w t)$ is the wild-type full-length cDNA. $H 4 / P D G F \beta R-\Delta E X$ lacks amino acids 101 to 368 of $H 4 ; H 4 / P D G F \beta R-\Delta L Z$ lacks the leucine zipper domain from amino acids 55 to 93 of $H 4$ moiety; H4/PDGF $\beta R$-WW contains $2 \mathrm{~W} \rightarrow$ A substitutions at positions $566 / 593$ of the $P D G F \beta R$ gene; $H 4 / P D G F \beta R$ - $634 R$ is a kinase-inactive mutant; and $H 4 / P D G F \beta R$-F2 contains $2 \mathrm{Y} \rightarrow \mathrm{F}$ mutations of residues $579 / 581$ of the $P D G F \beta R$ portion of the fusion. (B) H4/PDGF $\beta$ R transformation of Ba/F3 cells. H4/PDGF $\beta R$ was retrovirally transduced by retrovirus into $\mathrm{Ba} / \mathrm{F} 3$ cells, followed by selection with $\mathrm{G} 418(1 \mathrm{mg} / \mathrm{mL})$ in the presence of IL-3. After 7 days, the cells were washed and IL-3 was withdrawn. Cells were counted every 24 hours with the use of trypan blue solution $(0.4 \%)$ to distinguish between viable and nonviable cells. None of the H4/PDGF $\beta$ R mutants tested were able to efficiently induce IL-3-independent growth, although longer term culture allowed for eventual outgrowth of IL-3-independent clones (data not shown). Control experiments demonstrated that TEL/JAK2, but not a PGK-neo empty vector, conferred factor independence to Ba/F3 cells. (C) Expression of H4/PDGF $\beta$ R and related mutants. Expression of H4/PDGF $\beta$ R and related mutants was confirmed by Western blot analysis of $\mathrm{Ba} / \mathrm{F3}$ whole cell lysates by means of anti-PDGF $\beta R$ antibody as described in "Materials and methods." Expected band sizes are H4/PDGF $\beta R, 110 \mathrm{kd}$; H4/PDGF $\beta$ R $\Delta$ EX, $85 \mathrm{kd}$; and H4/PDGF $\beta R \Delta L \mathrm{LZ}, 105 \mathrm{kd}$. 

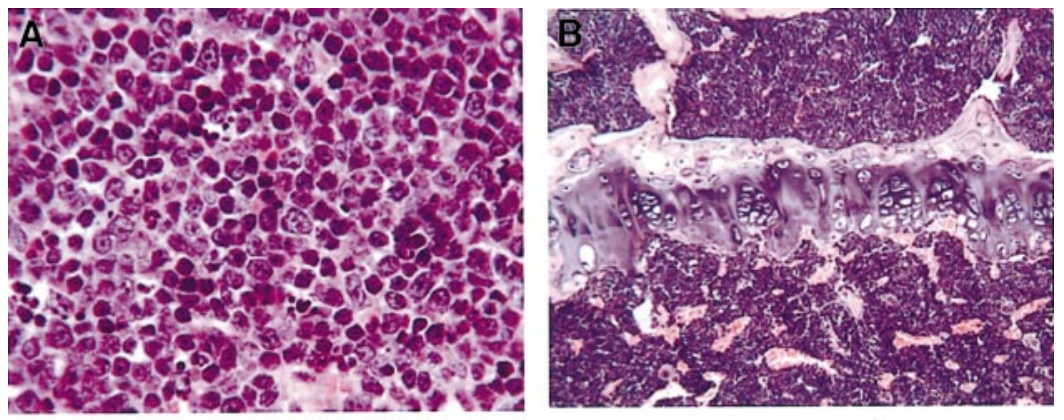

Figure 6. Histopathologic and flow-cytometric analysis of mice transplanted with bone marrow transduced by $\mathrm{H} 4$ / $P D G F \beta R$ retrovirus. Mice transplanted with bone marrow transduced with $H 4 / P D G F \beta R$ retrovirus develop a lethal hematopoietic malignancy after a latency of approximately 150 days. The disease is characterized by proliferation of immature $T$ cells $\left(\mathrm{CD}^{+/+}\right.$and $\mathrm{CD}^{+/+}$cells), with infiltration of spleen (A, highpower view), bone marrow (B, low-power view), and lymph node (C, high-power view). Flow cytometry of the lymph node (D) demonstrates a predominant $\mathrm{CD} 4^{+/+} \mathrm{CD} 8^{+/+} \mathrm{T}$-cell population.
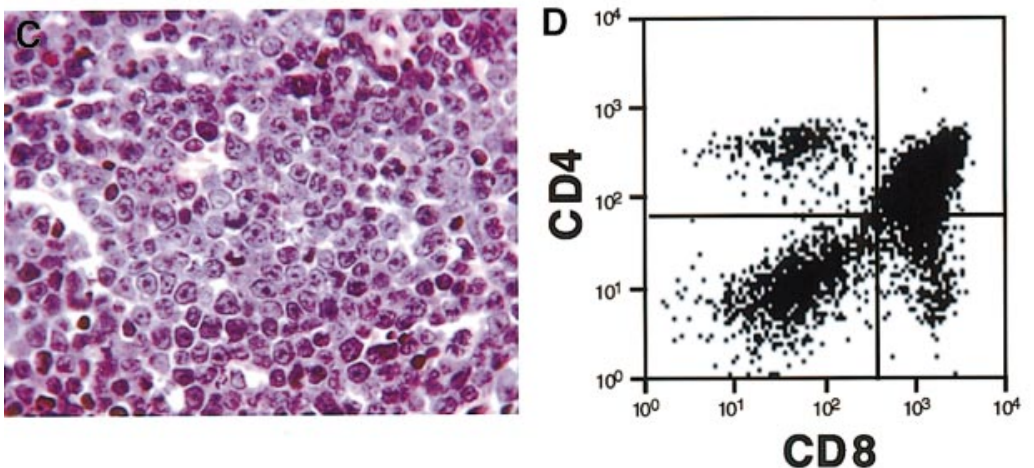

7A), and the neoplastic cells were monoclonal in spleen and bone marrow (Figure 7B). An additional, less-intense band indicative of biclonal disease was identified in lymph node and thymus. These data demonstrate that the H4/PDGF $\beta R$ fusion resulting from $\mathrm{t}(5 ; 10)(\mathrm{q} 33 ; \mathrm{q} 22)$ has transforming potential in vitro and in vivo.

\section{Discussion}

We have cloned a novel fusion between the $H 4(D 10 S 170)$ gene on chromosome $10 \mathrm{q}$ and $P D G F \beta R$ on $5 \mathrm{q}$, the result of a reciprocal $\mathrm{t}(5 ; 10)(\mathrm{q} 33 ; \mathrm{q} 22)$ in a patient with atypical CML. H4(D1OS170) encodes a ubiquitously expressed protein of unknown function and has been previously characterized as fusion partner of the RET receptor tyrosine kinase, ${ }^{20,22,23}$ whose ligand is the glial cell line-derived neurotrophic factor. $^{38,39}$ The H4/RET fusion is one of 6 known RET rearrangements associated with human papillary thyroid carcinoma and is found in approximately $25 \%$ of the cases. ${ }^{21}$

Both fusion genes involving the H4(D10S170) gene, H4/PDGF $\beta R$ and $H 4 / R E T$, are associated with a specific disease phenotype. Rearrangements of RET occur exclusively in papillary thyroid carcinomas, whereas $P D G F \beta R$ fusions have been associated with acute myeloid leukemia and chronic myeloproliferative syndromes. Both $\mathrm{H} 4$ fusion genes (H4/RET and H4/PDGF $\beta R$ ) have transforming activity in vitro and in vivo. In vitro transforming activity of H4/RET depends on the presence of the leucine zipper domain at the $5^{\prime}$ end of H4(D10S170), which acts as a dimerization/oligomerization motif leading to activation of the fused kinase domain. ${ }^{24}$ In addition, targeted expression of the RET/PTC1 oncogene induces papillary thyroid carcinomas in mice. ${ }^{40,41}$

There are several differences between H4/PDGF $\beta R$ and H4/RET. The H4/RET genomic breakpoint occurs in $H 4$ intron 1 and thus incorporates only the first exon of the H4(D10S170) gene. In contrast, the $H 4 / P D G F \beta R$ contains an additional 801 bp of $H 4(D 10 S 170)$ coding sequence. The function of this domain is unknown, although a protein sequence analysis reveals a series of $5 \times 29$ tandem repeats (positions 106-235,

SWISS-PROT Q16204) and a small second putative leucine zipper domain in this region (positions 265-278, Pfam 4.2, HMM search). H4/PDGF $\beta R$ conferred factor-independent growth to the IL-3-dependent hematopoietic cell line $\mathrm{Ba} / \mathrm{F} 3$ cells. Transformation activity was significantly impaired in H4/ $P D G F \beta R-\triangle L Z$ mutant lacking the amino-terminal leucine zipper domain, as well as the $H 4 / P D G F \beta R-\triangle E X$ mutant in which $H 4$ coding sequences unique to the $H 4 / P D G F \beta R$ fusion were deleted. These data suggest that there are functional components in each of these domains that are required for full transforming

A
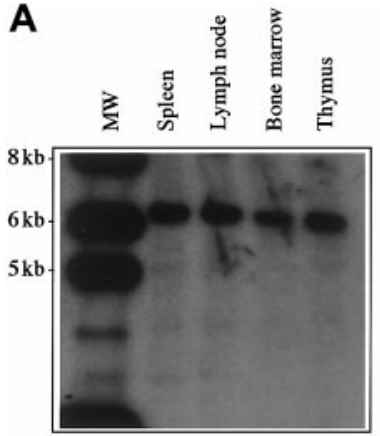

B
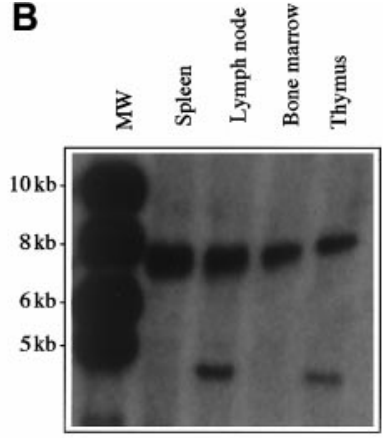

C

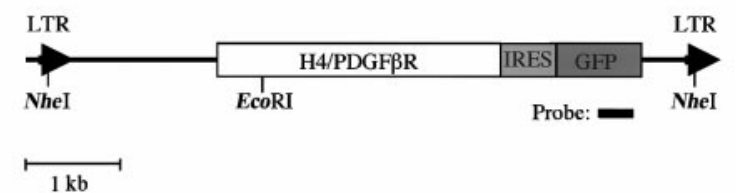

Figure 7. Analysis of proviral integration in disease tissue in transplanted mice. Southern blot analysis was performed with $10 \mu \mathrm{g}$ DNA extracted from murine tissues. (A) DNA was digested with the restriction enzyme Nhel, which cleaves in the viral long-terminal repeat sequences and demonstrates viral integration. The expected DNA band size is $5.8 \mathrm{~kb}$. (B) Clonality of the disease was assessed by digestion with EcoRl, which cleaves once within the provirus. There is clonal disease in spleen and bone marrow, and the presence of a second clone was detected in lymph node and thymus. (C) Restriction sites within the proviral sequence. 
activity in the $\mathrm{Ba} / \mathrm{F} 3$ assay. Additional mutational analysis will be required to further delineate these critical regions.

Mutations of the juxtamembrane tyrosine residues or in the WW-like domain of the H4/PDGF $\beta R$ also impaired factor-independent growth of $\mathrm{Ba} / \mathrm{F} 3$ cells. First, the H4/PDGF $\beta R-F 2$ mutant contains $\mathrm{Y} \rightarrow \mathrm{F}$ substitutions at PDGFßR residues 579/581 and participates in signal transduction to SRC and STAT family members. In the context of the H4/PDGFßR fusion, phenylalanine substitutions at positions 579/581 abrogate induction of IL-3-independent growth of $\mathrm{Ba} / \mathrm{F} 3$ cells. In addition, an analogous TEL/PDGF $\beta R$ F2 mutant also has impaired ability to confer factor-independent growth to $\mathrm{Ba} / \mathrm{F} 3$ cells (D.W.S. and D.G.G., unpublished observation, 2000) and is incapable of causing a myeloproliferative disease in a murine BMT model. ${ }^{15}$ Taken together, these data suggest that these juxtamembrane residues play an important role in the myeloproliferative phenotype associated with the H4/ PDGFßR and TEL/PDGFßR fusion proteins. Second, the $\mathrm{W} \rightarrow \mathrm{A}$ point mutations in the WW-like domain of H4/PDGF $\beta R$ impaired IL-3-independent survival of $\mathrm{Ba} / \mathrm{F} 3$ cells. These 2 tryptophan residues are characteristic of WW-domains, ${ }^{42}$ and a single amino acid substitution in the WW-like domain of the native PDGFßR causes constitutive activation of the receptor. ${ }^{43} \mathrm{WW}$ domains have been shown to associate with proline-rich motifs ${ }^{44-46}$ and with protein-phosphoserine and phosphothreonine motifs. ${ }^{47}$ We speculate that the WW-like domain of the H4/PDGF $\beta$ R fusion mediates direct interaction with downstream effector molecules and that disruption of these interactions through mutation impairs transformation of hematopoietic cells. Further analysis of the signal transduction and transforming properties of these mutants in vivo will be necessary to identify the relevant downstream effector molecules.

We next tested in vivo transforming activity of H4/PDGFßR in a murine BMT model. ${ }^{15,29}$ In this assay, expression of the tyrosine kinase fusion genes $B C R / A B L, T E L / J A K 2$, and TEL/PDGF $\beta R$ induces a lethal myeloproliferative syndrome with an average latency of 25 to 30 days..$^{15,29,36,37}$ However, mice transplanted with bone marrow transduced with a retrovirus encoding $H 4 / P D G F \beta R$ developed a long-latency T-cell lymphoblastic lymphoma/leukemia. These data demonstrate that H4/PDGF $\beta R$ transforms primary hematopoietic cells in the murine BMT assay. In addition, these data show that, although there is myeloid-lineage restriction of the $\mathrm{t}(5 ; 10)(\mathrm{q} 33 ; \mathrm{q} 22)$ translocation in human atypical CML, the H4/ PDGFßR fusion is capable of transformation of lymphoid cells. In a control experiment, mice transplanted with TEL/PDGFßR died of a myeloproliferative disease within 30 days, as expected. There are several possible explanations for the disparity in latency and phenotype between the TEL/PDGF $\beta R$ and H4/PDGF $\beta R$ fusions, including variable contribution to transformation by the $\mathrm{H} 4$ and TEL moieties, respectively. However, the most likely explanation is that H4/PDGFßR viral supernatants had a substantially lower titer than the TEL/PDGF $\beta$ R supernatants $\left(10^{-5}\right.$ vs $10^{-6} / \mathrm{mL}$, respectively), despite repeated efforts to generate higher titer H4/PDGF $\beta R$ retrovirus. TEL/PDGFßR BMT performed with viral supernatant titers of $10^{-5} / \mathrm{mL}$ also gives long-latency, clonally derived lymphoblastic lymphoma (D.W.S. and D.G.G., unpublished observation, 2000).

Another case of myeloproliferative disease associated with $\mathrm{t}(5 ; 10)(\mathrm{q} 33 ; \mathrm{q} 22)$ and an H4/PDGFßR fusion has recently been reported by Cross and colleagues, indicating that this is a recurring gene rearrangement. ${ }^{48}$

In summary, the H4/PDGF $\beta R$ fusion has transforming activity both in vitro and in vivo. Mutational analysis shows that transformation is dependent on the PDGF $\beta$ R-kinase domain. In addition, induction of factor-independent growth is impaired by deletion of $\mathrm{H} 4$ sequences encoding the amino-terminal leucine zipper domain. Induction of factor-independent growth is also impaired by deletion of $H 4$ sequences that are present in the H4/PDGFßR fusion, but absent in the H4/RET fusion associated with papillary thyroid carcinoma. In addition, mutation of PDGF $\beta R$ juxtamembrane tyrosine residues $579 / 581$ to phenylalanine, as well as $\mathrm{W} \rightarrow \mathrm{A}$ mutations of the WW-like domain, significantly impairs transformation in this assay. Further analysis of related mutations and assays in the murine BMT assay should provide additional insights into the mechanisms of transformation by the increasing number of $P D G F \beta R$ gene rearrangements associated with human leukemias.

\section{Acknowledgments}

The authors thank Francesca Garcia for administrative assistance and members of the Gilliland laboratory for valuable discussion. J.S. is a recipient of a Special Fellowship from the Leukemia Society of America, and D.G.G. is an Associate Investigator in the Howard Hughes Medical Institute.

\section{References}

1. Gilliland DG. Molecular genetics of human leukemia. Leukemia. 1998;12(suppl 1):S7-S12.

2. Sawyers CL. Chronic myeloid leukemia. N Engl J Med. 1999;340:1330-1340.

3. Peeters P, Raynaud SD, Cools J, et al. Fusion of TEL, the ETS-variant gene 6 (ETV6), to the receptor-associated kinase JAK2 as a result of $\mathrm{t}(9 ; 12)$ in a lymphoid and $\mathrm{t}(9 ; 15 ; 12)$ in a myeloid leukemia. Blood. 1997;90:2535-2540.

4. Eguchi M, Eguchi-Ishimae M, Tojo A, et al. Fusion of ETV6 to neurotrophin-3 receptor TRKC in acute myeloid leukemia with $\mathrm{t}(12 ; 15)(\mathrm{p} 13 ; \mathrm{q} 25)$. Blood. 1999;93:1355-1365.

5. Lacronique V, Boureaux A, Valle VD, et al. A TELJAK2 fusion protein with constitutive kinase activity in human leukemia. Science. 1997;278:13091312.

6. Reiter A, Schal J, Kulkarni S, et al. Consistent fusion of ZNF198 to the fibroblast growth factor receptor-1 in the $t(8 ; 13)(p 11 ; q 12)$ myeloproliferative syndrome. Blood. 1998;92:1735-1742.

7. Heldin $\mathrm{CH}$, Ostman A, Ronnestrand L. Signal transduction via platelet-derived growth factor receptors. Biochim Biophys Acta. 1998;1378:F79F113.

8. Golub TR, Barker G, Lovett M, Gilliland DG. Fusion of PDGF receptor beta to a novel ets-like gene, tel, in chronic myelomonocytic leukemia with $\mathrm{t}(5 ; 12)$ chromosomal translocation. Cell. 1994;77:307-316.

9. Abe A, Emi N, Tanimoto M, Terasaki H, Marunouchi T, Saito H. Fusion of the platelet-derived growth factor receptor beta to a novel gene CEV14 in acute myelogenous leukemia after clonal evolution. Blood. 1997; 90:4271-4277.

10. Ross TS, Bernard O, Berger R, Gilliland DG. Fusion of Huntingtin interacting protein 1 to plateletderived growth factor beta receptor (PDGFbetaR) in chronic myelomonocytic leukemia with $t(5 ; 7)(q 33 ; q 11.2)$. Blood. 1998;91:4419-4426.

11. Bennett JM, Catovsky D, Daniel MT, et al. The chronic myeloid leukaemias: guidelines for distinguishing chronic granulocytic, atypical chronic myeloid, and chronic myelomonocytic leukaemia: proposals by the French-American-British Coop- erative Leukaemia Group. Br J Haematol. 1994; 87:746-775.

12. Carroll M, Tomasson M, Barker GF, Golub TR, Gilliland DG. The TEL/platelet-derived growth factor beta receptor (PDGF $\beta R$ ) fusion in chronic myelomonocytic leukemia is a transforming protein that self-associates and activates PDGF $\beta$ R kinase-dependent signaling pathways. Proc Natl Acad Sci U S A. 1996;93:14845-14850.

13. Ross TS, Gilliland DG. Transforming properties of the Huntingtin interacting protein $1 /$ plateletderived growth factor beta receptor fusion protein. J Biol Chem. 1999;274:22328-22336.

14. Tomasson MH, Williams IR, Hasserjian $R$, et al. TEL/PDGFbetaR induces hematologic malignancies in mice that respond to a specific tyrosine kinase inhibitor. Blood. 1999;93:1707-1714.

15. Tomasson MH, Sternberg DW, Williams IR, et al. Fatal myeloproliferation, induced in mice by TEL/ PDGF $\beta$ R expresssion, depends on PDGF $\beta R$ tyrosines 579/581. J Clin Invest. 2000;105:423432.

16. Kolibaba KS, Drucker B. Protein tyrosine kinases 
and cancer. Biochim Biophys Acta. 1997;1333: F217-F248.

17. Bardelli A, Pugliese L, Comoglio PM. "Invasivegrowth" signaling by the Met/HGF receptor: the hereditary renal carcinoma connection. Biochim Biophys Acta. 1997;1333:M41-M51.

18. Ross JS, Fletcher J. HER-2/neu (c-erb-B2) gene and protein in breast cancer. Am J Clin Pathol. 1999;112(suppl 1):S53-S67.

19. Edery P, Eng C, Munnich A, Lyonnet S. RET in human development and oncogenesis. Bioessays. 1997;19:389-395.

20. Grieco M, Santoro M, Berlingieri MT, et al. PTC is a novel rearranged form of the ret proto-oncogene and is frequently detected in vivo in human thyroid papillary carcinomas. Cell. 1990;60:557563.

21. Sarasin A, Bounacer A, Lepage F, Schlumberger $\mathrm{M}$, Suarez HG. Mechanisms of mutagenesis in mammalian cells: application to human thyroid tumours. C R Acad Sci III. 1999;322:143-149.

22. Pierotti MA, Santoro M, Jenkins RB, et al. Characterization of an inversion on the long arm of chromosome 10 juxtaposing D10S170 and RET and creating the oncogenic sequence RET/PTC. Proc Natl Acad Sci U S A. 1992;89:1616-1620.

23. Grieco M, Cerrato A, Santoro M, Fusco A, Melillo $\mathrm{RM}$, Vecchio $\mathrm{G}$. Cloning and characterization of H4 (D10S170), a gene involved in RET rearrangements in vivo. Oncogene. 1994:9:2531. 2535.

24. Tong $Q$, Xing S, Jhiang SM. Leucine zipper-mediated dimerization is essential for the PTC1 oncogenic activity. J Biol Chem. 1997;272:9043-9047.

25. Siena S, Sammarrelli G, Grimoldi MG, et al. New reciprocal translocation $\mathrm{t}(5 ; 10)$ (q33;q22) associated with atypical chronic myeloid leukemia. Haematologica. 1999;84:369-372.

26. Dierlamm J, Wlodarska I, Michaux L, et al. Successful use of the same slide for consecutive fluorescence in situ hybridization experiments. Genes Chromosomes Cancer. 1996;16:261-264.

27. Jossart GH, O'Brien B, Cheng JF, et al. A novel multicolor hybridization scheme applied to localization of a transcribed sequence (D10S170/H4) and deletion mapping in the thyroid cancer cell line TPC-1. Cytogenet Cell Genet. 1996;75:254 257.
28. Weber-Matthiesen $\mathrm{K}$, Winkemann M, MuellerHermelink K, Schlegelberger B, Grote W. Simultaneous fluoresence immnophenotyping and interphase cytogenetics: a contribution to the characterization of tumor cells. J Histochem Cytochem. 1992;40:171-175.

29. Schwaller J, Frantsve J, Aster J, et al. Transformation of hematopoietic cell lines to growth-factor independence and induction of a fatal myelo- and lymphoproliferative disease in mice by retrovirally transduced TEL/JAK2 fusion genes. EMBO J. 1998;17:5321-5333.

30. Sozzi G, Bongarzone I, Miozzo M, et al. Cytogenetic and molecular genetic characterization of papillary thyroid carcinomas. Genes Chromosomes Cancer. 1992;5:212-218.

31. Smanik PA, Furminger TL, Mazzaferri EL, Jhiang SM. Breakpoint characterization of the ret/PTC oncogene in human papillary thyroid carcinoma. Hum Mol Genet. 1995;4:2313-2318.

32. Viglietto G, Chiapetta G, Martinez-Tello FJ, et al RET/PTC oncogene activation is an early event in thyroid carcinogenesis. Oncogene. 1995;11: 1207-1210.

33. Irusta PM, DiMaio D. A single amino acid substitution in a WW-like domain of diverse members of the PDGF receptor subfamily of tyrosine kinases causes constitutive receptor activation. EMBO J. 1998;17:6912-6923.

34. Drummond-Barbosa D, Vaillancourt RR, Kazlauskas A, DiMaio D. Ligand-independent activation of the platelet-derived growth factor beta receptor: requirements for bovine papillomavirus E5induced mitogenic signaling. Mol Cell Biol. 1995; 15;2570-2581.

35. Valgeirsdottir S, Pakku K, Silvenoinen O, Heldin $\mathrm{CH}$, Claesson-Welsh L. Activation of STAT5 by platelet-derived growth factor (PDGF) is dependent on phosphorylation sites in PDGF $\beta$-receptor juxtamembrane and kinase insert domains. Oncogene. 1998;16:505-516.

36. Pear WS, Miller JP, Xu L, et al. Efficient and rapid induction of a chronic myelogenous leukemia-like myeloproliferative disease in mice receiving P210 bcr/abl-transduced bone marrow. Blood. 1998;92: 3780-3792.

37. Zhang X, Ren R. Bcr-Abl efficiently induces a my- eloproliferative disease and production of excess interleukin-3 and granulocyte-macrophage colony-stimulating factor in mice: a novel model for chronic myelogenous leukemia. Blood. 1998 92:3829-3840.

38. Trupp M, Arenas E, Fainzilber M, et al. Functional receptor for GDNF encoded by the c-ret protooncogene. Nature. 1996;381:785-789.

39. Treanor JJ, Goodman L, de Sauvage F, et al. Characterization of a multicomponent receptor for GDNF. Nature. 1996;382:80-83.

40. Jhiang SM, Cho JY, Furminger TL, et al. Thyroid carcinomas in RET/PTC transgenic mice. Recent Results Cancer Res. 1998;154:265-270.

41. Santoro M, Chiapetta G, Cerrato A, et al. Development of thyroid papillary carcinomas secondary to tissue-specific expression of the RET/ PTC1. Oncogene. 1996;13:2021-2026.

42. Sudol M. Structure and function of the WW domain. Prog Biophys Mol Biol. 1996;65:113-132.

43. Irusta PM, DiMaio D. A single amino acid substitution in a WW-like domain of diverse members of the PDGF receptor subfamily of tyrosine kinases causes constitutive receptor activation. EMBO J. 1998;17:6912-6923.

44. Chen HI, Sudol M. The WW domain of Yes-associated protein binds a proline-rich ligand that differs from the consensus established for SRC homology 3-binding modules. Proc Natl Acad Sci U S A. 1995;92:7819-7823.

45. Staub O, Dho S, Henry P, et al. WW domains of Nedd4 bind to the proline-rich phosphotyrosine motifs in the epithelial $\mathrm{Na}+$ channel deleted in Liddle's syndrome. EMBO J. 1996;15:2371-2380.

46. Bedford MT, Chan DC, Leder P. FBP WW domains and the $\mathrm{Abl} \mathrm{SH} 3$ domain bind to a specific class of proline-rich ligands. EMBO J. 1997;16: 2376-2383.

47. Lu P-J, Zhou XZ, Shen M, Lu KP. Function of WW domains as phosphoserine- or phosphothreonine-binding modules. Science. 1999;283:13251328.

48. Kulkarni S, Heath $\mathrm{C}$, Parker $\mathrm{S}$, et al. Fusion of $\mathrm{H} 4 / \mathrm{D} 10 \mathrm{~S} 170$ to the platelet-derived growth factor receptor beta in BCR-ABL-negative myeloproliferative disorders with a $t(5 ; 10)(q 33 ; q 21)$. Cancer Res. 2000;60:3592-3598. 


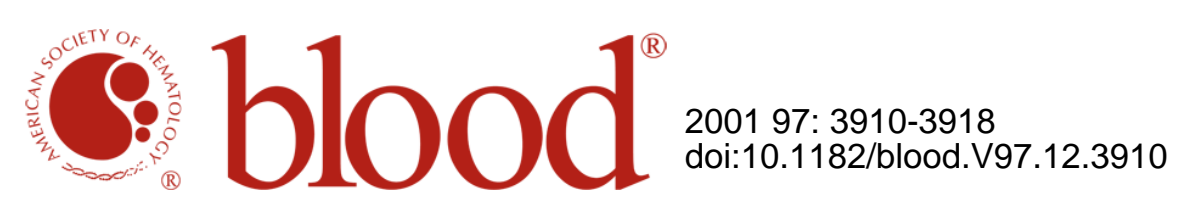

\section{$H 4(D 10 S 170)$, a gene frequently rearranged in papillary thyroid carcinoma, is fused to the platelet-derived growth factor receptor $\beta$ gene in atypical chronic myeloid leukemia with $t(5 ; 10)$ (q33;q22)}

Juerg Schwaller, Ema Anastasiadou, Danielle Cain, Jeff Kutok, Sarah Wojiski, Ifor R. Williams, Roberta LaStarza, Barbara Crescenzi, David W. Sternberg, Patrick Andreasson, Roberta Schiavo, Salvatore Siena, Cristina Mecucci and D. Gary Gilliland

Updated information and services can be found at:

http://www.bloodjournal.org/content/97/12/3910.full.html

Articles on similar topics can be found in the following Blood collections Neoplasia (4182 articles)

Information about reproducing this article in parts or in its entirety may be found online at: http://www.bloodjournal.org/site/misc/rights.xhtml\#repub_requests

Information about ordering reprints may be found online at:

http://www.bloodjournal.org/site/misc/rights.xhtml\#reprints

Information about subscriptions and ASH membership may be found online at:

http://www.bloodjournal.org/site/subscriptions/index.xhtml

Blood (print ISSN 0006-4971, online ISSN 1528-0020), is published weekly by the American Society of Hematology, 2021 L St, NW, Suite 900, Washington DC 20036.

Copyright Copyright (C) 2001 The American Society of Hematology by The American Society of Hematology; all rights reserved. 